\title{
SOCIAL MOODS OF THE POPULATION OF THE SOVIET REAR DURING THE STALINGRAD BATTLE
}

\author{
Vyacheslav N. Paramonov \\ Samara National Research University named after S.P. Korolev, Samara, Russian Federation
}

\begin{abstract}
The paper notes an increase in interest in studying the social moods of the population of the USSR rear during the Great Patriotic War. The problem of the "little man", an ordinary worker of the war, is actively investigated. Domestic historiography was supplemented by a number of historical and psychological studies of mass consciousness and its components, its role in achieving victory. However, in the opinion of the author, it is premature to consider the study of the social moods of the population of the Soviet rear as almost completely finished. On the basis of archival materials (Russian State Archive of Socio-Political History, Samara Regional State Archive of Socio-Political History, Central State Archive of the Samara Region), some of which have recently been declassified and introduced for the first time in scientific circulation, the paper analyzes the spectrum of public moods of the RSFSR citizens of the Soviet rear during the Stalingrad Battle of 1942-1943. The author also studies the factors that influenced the formation of moods and behavior of the population, including the influence of power on mass consciousness, the dynamics of moods, including attitudes toward war, the enemy and allies. The author shows the forms of behavior during the war, the reaction to events on the front, the perception of the war by population. The author comes to the conclusion that patriotic moods predominated as the conscious aspiration of Soviet people to defend the Fatherland at any cost, as a moral rejection of the Nazi policies by the people. The victory in the Battle of Stalingrad strengthened the conviction, the people's confidence in victory on all fronts.

Key words: The Great Patriotic War, the Battle of Stalingrad, social moods, mentality, authority, population, propaganda.
\end{abstract}

Citation. Paramonov V.N. Social Moods of the Population of the Soviet Rear during the Stalingrad Battle. Vestnik Volgogradskogo gosudarstvennogo universiteta. Seriya 4, Istoriya. Regionovedenie. Mezhdunarodnye otnosheniya [Science Journal of Volgograd State University. History. Area Studies. International Relations], 2018, vol. 23, no. 1, pp. 45-55. (in Russian). DOI: https://doi.org/10.15688/jvolsu4.2018.1.5

\section{СОЦИАЛЬНЫЕ НАСТРОЕНИЯ НАСЕЛЕНИЯ СОВЕТСКОГО ТЫЛА В ПЕРИОД СТАЛИНГРАДСКОЙ БИТВЫ}

\author{
Вячеслав Николаевич Парамонов \\ Самарский национальный исследовательский университет им. С.П. Королева, \\ г. Самара, Российская Федерация
}

Аннотация. В статье отмечается повышение интереса к изучению социальных настроений населения
тыла СССР в период Великой Отечественной войны. Активно исследуется проблема «маленького человека»,
рядового труженика войны. Отечественная историография пополнилась рядом историко-психологических 


\section{СТРАЛИНГРАДСКИЙ ТЫЛ}

исследований массового сознания и его составляющих, его роли в достижении победы. Однако, по мнению автора, считать изучение социальных настроений населения советского тыла почти полностью завершенным преждевременно. В статье на основе архивных материалов (РГАСПИ, СОГАСПИ, ЦГАСО), часть из которых недавно рассекречена и вводится впервые в научный оборот, анализируется спектр общественных настроений жителей РСФСР, находившихся в советском тылу в период Сталинградской битвы 1942-1943 гг., рассматривается совокупность факторов, влиявших на формирование настроений и поведение населения, включая влияние власти на массовое сознание, прослеживается динамика настроений, в том числе отношение к войне, противнику и союзникам, показаны формы поведения в условиях войны, освещается реакция на события на фронте, восприятие хода войны населением. Автор пришел к выводу о преобладании патриотических настроений как осознанного стремления советских людей защищать Отечество любой ценой, как нравственного неприятия народом политики нацистов. Победа в Сталинградской битве укрепила убеждение, уверенность населения в победе на всех фронтах.

Ключевые слова: Великая Отечественная война, Сталинградская битва, социальные настроения, менталитет, власть, население, пропаганда.

Цитирование. Парамонов В. Н. Социальные настроения населения советского тыла в период Сталинградской битвы // Вестник Волгоградского государственного университета. Серия 4, История. Регионоведение. Международные отношения. - 2018. - Т. 23, № 1. - С. 45-55. - DOI: https://doi.org/10.15688/jvolsu4.2018.1.5

В последние десятилетия наблюдается повышенный интерес к изучению социальных настроений населения тыла СССР. Активно исследуется проблема «маленького человека», рядового труженика войны. Отечественная историография пополнилась рядом историко-психологических исследований массового сознания и его составляющих, его роли в достижении победы $[2 ; 3 ; 5-7 ; 9 ; 10 ; 11 ; 13$; $14 ; 16 ; 17 ; 20 ; 22 ; 23 ; 25-29 ; 45 ; 46]$. Однако считать изучение социальных настроений населения советского тыла почти полностью завершенным преждевременно. В настоящей статье анализируется спектр общественных настроений жителей РСФСР, находившихся в советском тылу в период Сталинградской битвы 1942-1943 годов.

Хронологические рамки исследования охватывают период Сталинградской битвы (июль 1942 г. - февраль 1943 г.), когда динамика настроений населения советского тыла тесно увязывалась с событиями в Сталинграде, а сам город и в средствах массовой информации, и в массовом сознании представлялся как символ стойкости, мужества и героизма.

За первый год войны население СССР в большинстве своем избавилось от иллюзий, надежд на то, что немецкий рабочий класс повернет оружие против нацистов и осуществит революцию. Абсолютное большинство людей понимало, что нацистская Германия хочет захватить его родную землю и кончится это плохо. У многих к Гитлеру были лич- ные счеты, связанные с гибелью родственников от оккупантов.

Отступление советских войск летом 1942 г. порождало самые разные интерпретации среди населения. Агитатор, член ВКП(б) Кычев (завод им. Дзержинского, г. Молотов) так объяснял слушателям факты отступления Красной Армии: «Фашисты не ценят свой народ, а у нас в стране дорожат человеком, вот чтобы меньше было человеческих жертв, наши и отступают» ${ }^{1}$. Другой агитатор, член ВКП (б) Парфенов заявлял, что «наше командование видит, что держать эти рубежи нецелесообразно, и отступает, чтобы больше истребить людской силы и техники врага» [44, л. 125].

Осенью 1942 г. среди части населения были распространенными пораженческие настроения. Колхозник Романов (Куйбышевская обл.) говорил: «У немцев план таков - взять Сталинград, отрезать Баку, Москву от Сибири и тогда коммунистам бежать некуда. Все они умрут с голоду». Колхозник Кошелев заявлял: «Все равно нас немцы побьют. Сталинград окружен, скоро немцы сюда придут». Колхозница колхоза «Наша сила» Карсунского района Куйбышевской области Беляева заявляла: «Все, что мы делаем, достанется Гитлеру, так как в сентябре он придет сюда, не стоит напрасно работать в колхозе» [37, л. $75,127,182]$. Часть населения надеялась на приход Гитлера как альтернативу советской власти и коммунистам, колхозному строю. Значительное распространение получили слухи о хорошем обращении немцев с пленными 
и населением, оставшемся на оккупированной территории [37, л. 74, 127; 40, л. 372, 373, 388].

Отсутствие каких-либо убедительных официальных объяснений по поводу сложившегося критического положения, сокрытие правды, реальной картины боевых действий порождали слухи и домыслы, обижали и оскорбляли людей. Секретарь партбюро завода № 238 НКПС С.А. Павлов заявлял: «Наше правительство не думает и не видит, что у них ничего не получается, скорей бы этому был конец. Что это за советская власть, только все кричат: “мы возьмем, мы победим”, а сами не берут, все это только одно вранье» [37, л. 274].

Произведения М. Шолохова, К. Симонова, М. Эренбурга [24; 47; 48] послужили детонатором пропагандистской кампании, нацеленной на консолидацию советского населения для борьбы с внешним врагом, на создание некоего идола для ненависти, формирование четкого и понятного образа врага, против которого стоит копить злость и ненависть. Сравнительно нечасто встречаются в газетах откровенные проявления ненависти к немцам как нации. В качестве примера приведем заметку Я. Макаренко «Рабовладельцы-истязатели». В этой публикации автор анализирует содержание письма, обнаруженного у убитого немца, в котором жена пишет своему мужу, как поступать с русскими. В статье говорится: «Паршивая немка указывает своему мужу, гитлеровскому разбойнику, как поступать с русским населением. Пусть же зальется слезами ненасытная тварь, узнав о гибели своего разбойника-мужа. Пусть разорвется на части ее черное, поганое сердце. Священна пуля, сразившая гитлеровца. Слава воину, который метко пустил ее в сердце бандита!» [18].

Директор института мирового хозяйства и мировой политики АН СССР Е.С. Варга в докладе 25 сентября 1942 г. пытался проанализировать причины германской агрессии: «Каковы исходные причины ...хищнического характера немецкого империализма? - Иногда у нас с этим вопросом обращаются довольно просто. Говорят, немцы всегда были звери, всегда были разбойники, хищники и т. д. Это характер немцев. - Это, товарищи, конечно, абсолютно неправильный подход. Методологически это ничем не отличается от того, что говорят фашисты. Они говорят: немцы - это особая раса, которая лучше всех. А если мы на это говорим: нет, они хуже всех, - это не марксистский подход к вопросу. ...И другие народы в истории иногда показывали довольно-таки хищнические черты... Почти нет в мире такого народа, который в определенном этапе своей истории не играл бы роли завоевателя». Это противоречило официальной пропаганде, делавшей в тот момент акцент на том, немцы уже тысячу лет назад хотели завоевать территорию на Востоке и делавшей акцент на многовековой агрессивности немцев и т. д. Поэтому подобные высказывания Е.С. Варги оценивались как политически вредные, как оправдание захватнической политики гитлеровской Германии [36, л. 61-62].

К осени 1942 г. партийными органами были частично систематизированы представления советского населения относительно войны. На совещании секретарей обкомов ВКП(б) по пропаганде и агитации и редакторов областных газет в октябре 1942 г. отмечалось наличие ряда стереотипов-предрассудков в сознании населения: «во-первых... толкование вопроса о том, что союзники имеют ресурсов в несколько раз превышающие ресурсы гитлеровской коалиции, поэтому победа обеспечена... Второй предрассудок в пропаганде... что немецкая армия - армия разложившаяся, немецкая армия не имеет благородных целей войны, такая армия не может победить, чуть ли не все немцы сдаются в плен... Третий предрассудок - в отношении второго фронта... будто второй фронт избавление от всех бед, второй фронт решает все. Создавалось впечатление, что собственных сил не имеем... Четвертый предрассудок... в том, что у нас страна велика, пространства большие, поэтому есть куда отступать, отступать мы можем. Пятый предрассудок - это о наследии до войны. Когда говорили о представителях русского народа, когда говорили об ученых, деятелях искусства, то их изображали как продукт западноевропейского влияния». На совещании ставилась задача «поднять знамя русской культуры», подчеркивалось, что мы «должны противопоставлять гитлеровской пропаганде нашу культуру» [35, л. 42 об.-43].

На восприятии противника населением советского тыла сказывались поездки делегаций на фронт и рассказы затем о том, что 


\section{СТРАЛИНГРАДСКИЙ ТЫЛ}

там происходит. Приведем только один пример. В декабре 1942 г. начальник инструментального цеха Куйбышевского механического завода В.Я. Келехсаев побывал в сражающемся Сталинграде. Вернувшись на завод, он привез с собой немецкую амуницию. Слесарьинструментальщик этого цеха А.М. Ляшенко вспоминал: «С большим интересом рабочие рассматривали немецкую военную рубашку и, когда в складках обнаружили следы гнид, удивлению не было предела: “Да их и вши едят такие же, как нас!” - воскликнул один из рабочих. “А они и сами такие же, как мы, обыкновенные люди”, - пояснил Келехсаев, своими глазами видевший в Сталинграде пленных немцев. "Этого быть не может, - снова закричал кто-то. - А тогда почему они убивают, расстреливают, жгут, вешают на виселицах мирных людей? Разве так поступают обыкновенные люди? Нет, это изверги, звери! Да у них и рога-то на касках", - горячо продолжал пожилой рабочий, беря в руки немецкую каску с короткими рожками по бокам. “А это что за обувь? - возмущался третий, демонстрируя собравшимся огромные соломенные сапоги, которые фрицы надевали поверх своей обуви. - Разве нормальные люди носят страсть такую? Нет! Это не люди, а черти какие-то"» $[1$, с. 146].

Положительный настрой и нацеленность на победу воплощались в конкретных делах. В дни Сталинградской битвы становится популярным призыв «Работай так, как сражаются сталинградцы». Ответом на него стали декадники и месячник дополнительной помощи сталинградцам, фронтовые вахты [4; 42, л. 179-180].

Массовый характер приобрел сбор средств на вооружение. В сентябре 1942 г. с саратовского аэродрома поднялся самолет, ведомый Героем Советского Союза гвардии майором Василием Шишкиным. На борту самолета алела надпись: «Герою Советского Союза майору Шишкину В.И. от колхозников колхоза “Сигнал революции”, Ворошиловского района, Саратовской области». Это был первый в Союзе самолет, приобретенный на средства колхозников [15]. Подобные примеры не были единичны [21].

16 декабря 1942 г. было опубликовано обращение коллектива завода им. Масленни- кова к трудящимся Куйбышевской области, в котором говорилось: «Мы вносим 400000 рублей на строительство эскадрилий самолетов авиаполка “Валериан Куйбышев”. .. призываем рабочих, работниц, инженеров, техников и служащих всех предприятий, учреждений и организаций г. Куйбышева и других городов Куйбышевской области последовать нашему примеру» [19, л. 61]. В области начался сбор средств на постройку полка авиаэскадрилий. Уже к началу февраля 1943 г. были собраны средства на строительство 42 самолетов [38, л. 144].

Огромное значение имели письма с фронта и на фронт, свидетельствовавшие о неразрывной связи Красной Армии и тыла. Участники собрания актива Куйбышевской областной парторганизации обращались к сталинградцам: «Мы... заверяем вас и клянемся, что не пожалеем сил, чтобы дать все необходимое для защиты Сталинграда» [43, л. 1]. Учителя и учащиеся Куйбышевской области 20 октября 1942 г. обращались к сталинградцам: «Мы крепко верим в то, что не сломить проклятым гитлеровцам вашей стойкости, не побороть вашего мужества и силы. Мы знаем, что вы не сдадите воинскую твердыню Сталинград, не пустите врагов на Волгу, не отдадите нас, своих детей в рабство ненавистным немцам. Желаем вам, родные наши защитники, здоровья, бодрости, боевых успехов. Помните, что ваши дети мысленно с вами» [41, л. 208б, 208в].

Тревогу и критику среди советского населения вызывало затягивание с открытием второго фронта в Европе. Жителей СССР волновали вопросы о том, скоро ли будет открыт второй фронт; какими путями идет помощь СССР от Америки и Англии; является ли война США против Японии справедливой; почему Америка, передовая страна, терпит поражения, отдает острова Японии; имеют ли место гденибудь совместные военные действия СССР и Англии; не ведет ли Англия политику истощения в войне Германии и СССР; есть ли у нас возможность разбить фашистскую армию, если не будет второго фронта в Европе; не могут ли изменить нам наши союзники [32, л. $158 ; 33$, л. 5 об., 63, 102; 34, л. 64 об.; 39, л. 224].

Значение первой крупной операции западных союзников в Африке в 1942 г. было положительно оценено советской общественнос- 
тью. Доктор геологических наук, сотрудник института АН СССР А.А. Сауков заявлял: «События в Африке - это, безусловно, начало второго фронта». Подобные оценки высказывали и другие ученые, трудившиеся в Свердловске. Профессор И.К. Кикоин: «Африка - это второй фронт. Но все же нужно готовиться к затяжной войне, которая может продлиться до 1945 года. Успокаивать себя нельзя». Академик А.Д. Шевяков: «Немцы еще сильны и не считаться с этим нельзя». Академик М.В. Кирпичев: «Положение Советского Союза тяжелое, но самое опасное уже осталось позади. Разгром Гитлера неизбежен» [30, л. 5-6].

Управление пропаганды и агитации ЦК ВКП(б) в тезисах доклада о текущем моменте в 1942 г. акцентировало внимание на том, что помощь, «оказываемая нам Англией и США, пока мало эффективна по сравнению с той помощью, которую оказывает им СССР, оттягивая на себя основные силы гитлеровской армии» [39, л. 237]. Эта позиция была близка, судя по источникам, и большинству тылового населения.

Многие жители тыла опасались вмешательства Англии и США во внутренние дела СССР. Так, слесарь Рузаевского паровозного депо С. Лаврушев говорил: «Мы так и будем драться, пока весь народ не перебьют, а потом Англия нас возьмет в свои руки. Англия сейчас уже требует, чтобы наши войска носили английскую форму, начнется понемногу, а кончится большим». Токарь этого же депо Балясников говорил: «Англия и Америка постепенно начинают внедрять свои порядки». Рабочий станции Ульяновск М.П. Зуев отмечал: «Сейчас у нас все идет под диктовку Америки, в долги которой СССР влез, а теперь нам с ней не расплатиться». Рабочий Куйбышевского паровозного депо Ульянов заявлял: «Я предполагаю, что у нас много делается сейчас под нажимом Англии и Америки, а наше правительство, нуждаясь в помощи, идет на уступки» [31, л. 21 об.].

Часть населения не принимала введение погон и возрождение в Красной Армии офицерских званий, особенно полковника и генерала, которые напоминали им участников Белого движения, а другие не одобряли тот факт, что Сталин наденет мундир с погонами [14, c. 205], расценивали это как «возвращение к прошлой дореволюционной жизни», как «сдачу классовых позиций» [31, л. 22 об.].

Следует выделить антикоммунистическую направленность части высказываний. В колхозе «Красный Октябрь» Карсунского района (Куйбышевская область) единоличник Лазарев говорил: «Настало время, что через полтора месяца колхозы полетят и мы, честные люди, будем делить землю и скот... А у коммунистов и активистов отделят головы». На общем собрании колхозников колхоза «Новый путь» Дубово-Уметского района Н.3. Симонов заявлял: «Партия маскируется, обманывает народ. В ней нет честных людей - одни жулики. Вы думаете, что народ слепой. Скоро придет время, народ свое скажет». Колхозница Н.И. Унягина из колхоза им. Чапаева Тагайского района говорила: «Мы скоро дождемся того дня, когда мне вернут дом и все имущество, а с теми, кто взял у нас имущество, мы расправимся» [37, л. 74; 40, л. 388 об.].

Распространенными были антиколхозные настроения и ожидания роспуска колхозов. Показательны мнения колхозников Куйбышевской области. Член ВКП(б) председатель колхоза «Луч Ильича» Кинельского района И.В. Букалин среди колхозников говорил: «Лучше в тюрьме сидеть, чем в колхозе работать. Колхоз хуже тюрьмы. Хлеб уберем, сдадим государству, а сами останемся без хлеба». Схожее высказывание мы находим у колхозника Романова (колхоз им. Сталина Павловского района): «Наши колхозы - это яма поганая. Все говорят свобода - кому бы передать эту свободу». Колхозник колхоза «31 января» Сызранского района Федотов в присутствии колхозников отмечал: «Колхозы не имеют своего будущего, они все равно скоро распадутся, потому что советская власть не подготовила руководителей для колхозов». Колхозник Новоспасского района Новоженин, саботируя работу в колхозе, заявлял: «Советская власть издевается над колхозниками, озлобляет последних, а потому они на работу в колхозе не выходят». Колхозница колхоза им. Калинина Кинельского района Е.П. Уварова высказывалась: «Замучили нас работой в колхозе, не дают легко издохнуть. Колхозница Алексеева колхоза «Путь к коммунизму» Павловского района говорила: «Колхозы, а особенно брига- 


\section{СТРАЛИНГРАДСКИЙ ТЫЛ}

диры, нам надоели. Каждый день только и гонят на работу». Колхозник Ожерельев из колхоза им. Апасова Борского района объяснял: «Колхозники плохо работают потому, что труд в колхозе подневольный. В связи с этим колхозный труд долго не просуществует. Это не мое мнение, а мнение многих колхозников». В колхозе им. Сталина Павловского района колхозница Кулакова говорила: «Видимо, никогда не дождемся, когда будет конец колхозам. Сдохнем все от колхозной работы. Каждый день гонят на работу. До войны мучились - хорошего ничего не видели, а теперь также не увидим» [37, л. 75; 40, л. 367, 371, 372, 388-388 об.].

Рабочие промышленных предприятий чаще всего жаловались на плохую организацию работы, низкую зарплату, нехватку продуктов, злоупотребления местных властей. Обращает на себя внимание непритязательность пожеланий людей, требовавших всего лишь обеспечения установленного прожиточного минимума и ничего сверх того [12, л. $6,9,14]$.

Анализ источников показывает наличие среди части населения тыла антисемитских настроений. Например, был зафиксирован случай, когда рассказ слесаря авиационного завода № 1 Кудинова о якобы услышанных им от очевидцев примерах отношения немецких фашистов к евреям вызвал среди слушавших его учеников антисемитские настроения, сопровождавшиеся выкриками: «Бей жидов, спасай Россию!», «Война началась из-за евреев», «Во всем виноваты евреи» и т. п. [37, л. 369 об.].

И все-таки вера в победу советского народа в войне была преобладающей. Успешное наступление Красной Армии в районе Сталинграда вызвало оживление и рост положительных настроений. В справке Куйбышевского управления НКВД от 19 января 1943 г. о политических настроениях населения области содержатся позитивные оценки происходящего. Доцент Пединститута Бочкарев перед началом занятий говорил: «Душа радуется, когда слушаешь замечательные известия с фронтов Отечественной войны. Сталин тысячу раз оказался прав, говоря, что скоро враг на своей шкуре почувствует наши удары». Другой доцент Пединститута Радкович в общежитии, слушая передачу последних известий, отмечал: «Мы сейчас как-то легче стали дышать, и сердце радуется, когда слушаешь
“В последний час"». Кандидат филологических наук Метченко сказал: «События на фронте за последние дни исключительно велики, они предвещают скорую победу и немедленную гибель немецких войск» [37, л. 269 об.].

«Большую радость вызвало сообщение о полной ликвидации немецких войск в районе Сталинграда», - записал в своем дневнике 3 февраля 1943 г. горьковчанин профессор Н.М. Добротвор [8, с. 530].

Победа в Сталинградской битве породила излишне оптимистические ожидания относительно разгрома нацистской Германии и окончания войны, о чем свидетельствуют высказывания работников тыла в январе 1943 г. Рабочие подъемного цеха депо станции Ульяновск выразили уверенность, что Красная Армия хорошо подготовилась к наступлению и разгром немцев наступит в 1943 году. Группа машинистов депо Уфа выразила уверенность в победе над немцами в ближайшее время. Помощник машиниста беспартийный В.Н. Степанов заявил: «Если, товарищи, мы так будем гнать немцев, то к весне свою территорию от них очистим и будем их уничтожать на их собственной земле. При таком успехе в Германии может произойти революция». Инженер-испытатель моторостроительного завода (г. Куйбышев) № 24 Мавренков так оценивал ситуацию на фронте: «Надо ожидать, что 1943 г. будет годом окончательного разгрома врага, потому что после такого поражения немецкая армия не способна будет сопротивляться, тем более вести наступательные бои... Вера в скорую победу как-то дает новую энергию, пропадает усталость и хочется работать без отдыха». Преподаватель Учительского института А.В. Шелесов: «Я верю, что в 1943 г. война кончится разгромом немцев». Мастер авиазавода № 1 В.И. Жарков: «Всякая перспектива Гитлера провалилась... Я надеюсь, при таком катастрофическом положении гитлеровской армии и благополучии наших войск война кончится в 1943 году». Рабочий завода имени Масленникова А.Я. Макаровский: «Работая на заводе я чувствую себя как на фронте и забываю о всех трудностях, которые приходится переносить в связи с войной». Кадровый рабочий с завода № 24 С.В. Атласов: «После таких сообщений неохота спать, хочется быстрее идти на завод и во имя нашей победы и быстрейшего 
разгрома врага работать и работать, не покладая рук» [31, л. 20 об., 33 об., 34 об., 35 об., 36].

Конечно, было и немало сомневающихся в неизбежности победы. Среди рабочих Куйбышеского железнодорожного узла наступление Красной Армии рассматривалось в январе 1943 г. как временное, и часть этих работников выражала неверие в победу. Главный кондуктор вагонного резерва Юрий Галицкий заявлял: «Наши плохо двигаются. У нас взяли немцы города, а наши берут только населенные пункты, наши никогда не освободятся от немцев». Преподаватель СШ № 23 Дерябина сказала: «Какие бы ни были успехи наших войск в зимний период, весной немцы обратно пойдут в наступление, потому что они сильнее нас техникой и вооружением, кроме того, немцы большие патриоты своей родины, вот посмотрите, даже будучи в трудных условиях блокады, решили принять бой, но не сдаться, лучше умереть со славой». Контролер 10-го цеха завода № 24 Д.В. Коновалов: «Немцы еще сильны и напрасно вы думаете, что дело идет к концу, они весной будут наступать снова, и так поднажмут, что всем будет жарко» [31, л. 22, 37 об.].

Разумеется, в статье приведен не весь спектр настроений населения советского тыла в период Сталинградской битвы. Следует отметить преобладание патриотических настроений как осознанного стремления советских людей защищать Отечество любой ценой, как нравственного неприятия народом политики нацистов. Победа в Сталинградской битве укрепила убеждение, уверенность населения в победе на всех фронтах.

\section{ПРИМЕЧАНИЕ}

1 Цитаты из архивных документов приводятся с сохранением авторской орфографии и пунктуации.

\section{СПИСОК ЛИТЕРАТУРЫ}

1. Безымянка. Строки, опаленные войной : кн. воспоминаний ветеранов Киров. р-на г. Самары / отв. ред. П. Л. Моисеенко. - Самара : ПАДИ, 1997. T. $1 .-416 \mathrm{c}$.

2. Великая Отечественная война 1941-1945 годов : в 12 т. Т. 10. Государство, общество, война. М. : Кучково поле, 2014. - 864 c.
3. Война и общество в XX веке : в 3 кн. Кн. 2. Война и общество накануне и в период Второй мировой войны. - М. : Наука, 2008. - 676 с.

4. Волжская коммуна (Орган Куйбышевского обкома и горкома ВКП(б), Облисполкома и Горсовета). - 1942. - 4 нояб. - С. 3 (Тематическая страница «Тебе, Сталинград!»).

5. Вольхин, А. И. Характер информирования органами НКВД-НКГБ СССР руководства страны о политических настроениях тружеников тыла в годы Великой Отечественной войны (на материалах Урала и Сибири) / А. И. Вольхин // Исторические чтения на Лубянке: 2002 год. - М. : ФСБ РФ, 2003. C. $158-163$.

6. Головченко, Е. И. Образ немца в частушках, анекдотах и стихотворениях в годы Великой Отечественной войны (по материалам газет «Коммуна», «Коллективный труд» и Комитета по радиовещанию Воронежской области) / Е. И. Головченко // Социальные и социально-педагогические проблемы: поиски и модели решения : межвуз. сб. науч. тр. - Воронеж : ВГПУ, 2007. - Вып. 6. C. 121-131.

7. Горяева, Т. М. Политическая цензура в СССР. 1917-1991 гт. / Т. М. Горяева. -М. : РОССПЭН, 2009. $-407 \mathrm{c}$.

8. Забвению не подлежит. Страницы нижегородской истории (1941-1945 годы). - Н. Новгород : Волго-Вят. кн. изд-во, 1995. - Кн. 3. -670 с.

9. Зима, В. Ф. Менталитет народов России в войне. 1941-1945 гг. / В. Ф. Зима. - М. : ИРИ РАН, $2000 .-277 \mathrm{c}$.

10. Зинич, М. С. Будни военного лихолетья, 1941-1945 / М. С. Зинич. - М. : РАН. Ин-т российской истории, 1994. - Вып. 1. - 147 с.

11. Зинич, М. С. Будни военного лихолетья, 1941-1945 / М. С. Зинич. - М. : РАН. Ин-т российской истории, 1994. - Вып. 2. - 143 с.

12. Информации и сообщения о настроениях населения в ЦК ВКП(б) // Российский государственный архив социально-политической истории (далее - РГАСПИ). - Ф.17. - Оп. 121. - Д. 212.

13. Кабирова, А. Ш. Массовое сознание населения Татарстана в годы Великой Отечественной войны (1941-1945) / А. Ш. Кабирова // Вторая мировая война как проблемы национальной памяти : материалы междунар. науч. конф. (24-26 сент. 2009 г., г. Санкт-Петербург). - СПб. : Изд-во РГПУ им. А.И. Герцена, 2010. - С. 111-124.

14. Козлов, Н. Д. Официальное и обыденное сознание в годы Великой Отечественной войны / Н. Д. Козлов, М. М. Довжинец. - СПб. : Альтер Эго, 2008. - $336 \mathrm{c}$.

15. Коммунист (Орган Саратовского обкома и горкома ВКП(б), Облисполкома и Горсовета). -1945. -7 янв. - Передовая. 


\section{СТРАЛИНГРАДСКИЙ ТЫЛ}

16. Кондакова, Н. И. Война, государство, общество. 1941-1945 / Н. И.Кондакова. - М. : МГФ «Ветеран Москвы», 2002. - 480 с.

17. Кринко, Е. Ф. История Второй мировой войны в слухах / Е. Ф. Кринко // Вестник Сочинского государственного университета туризма и курортного дела : научн. журн. - 2008. - Вып. 12 (34). C. 194-203.

18. Макаренко, Я. Рабовладельцы-истязатели / Я. Макаренко // Киржачский ударник (Орган Киржачского горкома и райкома ВКП(б)). - 1942. 25 сент.

19. Письмо-обращение работников з-да им. Масленникова. Справки и отклики // Самарский областной государственный архив социально-политической истории ( далее-СОГАСПИ). - Ф. 656. Оп. 33. - Д. 74.

20. Потемкина, М. Н. Эвакуация в годы Великой Отечественной войны на Урале: люди и судьбы / М. Н. Потемкина. - Магнитогорск : МаГУ, 2002. $265 \mathrm{c}$.

21. Путь Ленина (Орган Ульяновского райкома ВКП(б) и районного Совета депутатов трудящихся). - 1943. - 1 янв. (№ 1). - С. 1 (Передовая).

22. Савушкин, Л. М. Идеология советского тыла: проблемы и противоречия, 1941-1945 гг. : (Опыт деятельности парт. орг. тыловых р-нов РСФСР) / Л. М. Савушкин. - Воронеж : Изд-во Воронеж. ун-та, 1990. - $191 \mathrm{c}$.

23. Сенявская, Е. С. Героические символы: реальность и мифология войны / Е. С. Сенявская // Отечественная история. - 1995. - № 5. - С. 30-44.

24. Симонов, К. С. Убей его / К. С. Симонов // Красная звезда. - 1942. - 18 июля.

25. Советская повседневность и массовое сознание 1939-1945 / сост. А. Я. Лившин, И. Б. Орлов. - М. : РОССПЭН, 2003. - 472 с.

26. Советская пропаганда в годы Великой отечественной войны: «коммуникация убеждения» и мобилизационные механизмы / авт.-сост. А. Я. Лившин, И. Б. Орлов. - М. : РОССПЭН, 2007. - 806 с.

27. Сомов, В. А. Первое советское поколение: испытание войной / В. А. Сомов. - М. : АИРО-ХХІ, 2015. - $176 \mathrm{c}$.

28. Сомов, В. А. Потому что была война... Внеэкономические факторы трудовой мотивации в годы Великой Отечественной войны (1941-1945) / В. А. Сомов. - Н. Новгород : Изд-во Волго-Вятской академии государственной службы, 2008. - 234 с.

29. Сомов, В. А. Слухи как фактор трудового поведения в начальный период великой отечественной войны / В. А. Сомов// Историческая психология и социология истории. - 2011. - № 1. - С. 19-32.

30. Сообщение Свердловского УНКВД в ЦК ВКП(б) об откликах ученых на действия союзников в Африке // РГАСПИ. - Ф. 17. - ОП. 125. - Д. 84.
31. Сообщения УНКВД в Куйбышевский обком ВКП(б) // СОГАСПИ. -Ф. 656. - ОП. 22. - Д. 20.

32. Сообщения УНКВД в Куйбышевский обком ВКП(б) // СОГАСПИ. - Ф. 656. - ОП. 33. - Д. 25.

33. Сообщения УНКВД в Куйбышевский обком ВКП(б) // СОГАСПИ. - Ф. 656. - Оп. 33. - Д. 38.

34. Сообщения УНКВД в Куйбышевский обком ВКП(б) // СОГАСПИ. - Ф. 656. - ОП. 34. - Д. 62.

35. Справки и докладные записки Куйбышевского обкома ВКП(б) // СОГАСПИ. - Ф. 656. -Оп. 33. Д. 72.

36. Справки и докладные записки ЦК ВКП(б) // РГАСПИ. - Ф.17. - ОП. 125. - Д. 203.

37. Справки и докладные УНКВД в Куйбышевский обком ВКП(б) о настроениях населения // СОГАСПИ. - Ф. 656. - ОП. 20. - Д. 33.

38. Справки и докладныеЦКВКП(б) // РГАСПИ.Ф. 17.-Оп. 43. - Д. 1474.

39. Справки и переписка Куйбышевского обкома ВКП(б) // СОГАСПИ. - Ф. 656. - Оп. 33. - Д. 35.

40. Справки о настроениях населения // СОГАСПИ. - Ф. 656. - ОП. 20. - Д. 32.

41. Справки, письма, отчеты Куйбышевского обкома ВЛКСМ // СОГАСПИ. -Ф. 1683. -Оп. 1. - Д. 204.

42. Справки статистического управления Куйбышевской области // Центральный государственный архив Самарской области. - Ф. Р-2521. Оп. 10. -Д. 73.

43. Справки ЦК ВКП(б) // РГАСПИ. - Ф. 17. Оп. 43. - Д. 1053.

44. Справки ЦК ВКП(б) по заводу им. Дзержинского // РГАСПИ. - Ф. 17. - ОП. 125. - Д. 108.

45. Ткачева, Г. А. Дальневосточное общество в годы Великой Отечественной войны (1941-1945 гг.) / Г. А. Ткачева. - Владивосток : Дальнаука, 2010. $376 \mathrm{c}$.

46. Точенов, С. В. Настроения населения Ивановской области на начальном этапе Великой Отечественной войны (июнь-август 1941 года) / С. В. Точенов // Вестник Ивановского государственного университета. Серия Гуманитарные науки. Научные статьи. - 2008. - Вып. 4. - С. 43-52.

47. Шолохов, М. А. Наука ненависти / М. А. Шолохов // Правда. - 1942. - 22 июня.

48. Эренбург, И. Убей / И. Эренбург // Красная звезда. $-1942 .-24$ июля.

\section{REFERENCES}

1. Moiseenko P.L., ed. Bezymyanka. Stroki, opalennye voynoy: $k n$. vospominaniy veteranov Kirov. r-na g. Samary [Bezymyanka. The Lines Scorched by the War: Book of Memories of Kirov Veterans of the District in the City of Samara]. Samara, PADI Publ., 1997, vol. 1. 416 p. 
2. Velikaya Otechestvennaya voyna 19411945 godov: v 12 t. T. 10. Gosudarstvo, obshchestvo, voyna [The Great Patriotic War of 1941-1945: in 12 vols. Vol.10. State, Society, War]. Moscow, Kuchkovo pole Publ., 2014. 864 p.

3. Voyna i obshchestvo $v$ XX veke: $v 3 \mathrm{kn}$. Kn. 2. Voyna $i$ obshchestvo nakanune $i$ period Vtoroy mirovoy voyny [War and Society in the $20^{\text {th }}$ Century. In 3 Books. Book. 2. War and Society on the Eve and During World War II]. Moscow, Nauka Publ., 2008. $676 \mathrm{p}$.

4. Volzhskaya kommuna (Organ Kuybyshevskogo obkoma i gorkoma VKP (b), Oblispolkoma i Gorsoveta) [The Volga Commune (the Body of the Kuibyshev Regional Committee and City Committee of the All-Union Communist Party (Bolsheviks), Regional Executive Committee and the City Council], 1942, November 4, p. 3 (Thematic page "Stalingrad, this is for you!").

5. Volkhin A.I. Kharakter informirovaniya organami NKVD-NKGB SSSR rukovodstva strany o politicheskikh nastroeniyakh truzhenikov tyla $\mathrm{v}$ gody Velikoy Otechestvennoy voyny (na materialakh Urala i Sibiri) [The Nature of Informing the Authorities of the NKVD-NKGB of the USSR about the Political Mood of Rear Workers During the Great Patriotic War (Based on Materials of the Urals and Siberia)]. Istoricheskie chteniya na Lubyanke: 2002 god [Historical Readings on Lubyanka: 2002]. Moscow, FSB RF Publ., 2003, pp. 158-163.

6. Golovchenko E.I. Obraz nemtsa v chastushkakh, anekdotakh i stikhotvoreniyakh v gody Velikoy Otechestvennoy voyny (po materialam gazet «Kommuna», «Kollektivnyy trud» i Komiteta po radioveshchaniyu Voronezhskoy oblasti) [The Image of the German in Folk Songs, Anecdotes and Poems During the Great Patriotic War (Based on the Materials of the Newspapers Kommuna, Collective Labor and the Radio Broadcasting Committee of the Voronezh Region)]. Sotsialnye i sotsialno-pedagogicheskie problemy: poiski i modeli resheniya: mezhvuz. sb. nauch. tr. [Social and Socio-Pedagogical Problems: Search and Models of Solutions. Interuniversity Collection of Academic Papers]. Voronezh, VGPU Publ., 2007, iss. 6, pp. 121-131.

7. Goryaeva T.M. Politicheskaya tsenzura v SSSR. 1917-1991 gg. [Political Censorship in the USSR. 19171991]. Moscow, ROSSPEN Publ., 2009. 407 p.

8. Zabveniyu ne podlezhit. Stranitsy nizhegorodskoy istorii (1941-1945 gody). Kn. 3 [Not Subject to Oblivion. Pages of Nizhny Novgorod History (1941-1945). Book 3]. Nizhny Novgorod, Volgo-Vyat. kn. izd-vo, 1995. 670 p.

9. Zima V.F. Mentalitet narodov Rossii v voyne. 1941-1945 gg. [Mentality of the Russian Peoples in the War. 1941-1945]. Moscow, IRI RAN Publ., 2000. $277 \mathrm{p}$.
10. Zinich M.S. Budni voennogo likholetya, 1941-1945 [Weekdays of the Military Hard Times, 1941-1945]. Moscow, In-t rossiyskoy istorii RAN Publ., 1994, iss. 1.147 p.

11. Zinich M.S. Budni voennogo likholetya, 1941-1945 [Weekdays of the Military Hard Times, 1941-1945]. Moscow, In-t rossiyskoy istorii RAN Publ., 1994 , iss. 2.143 p.

12. Informatsii i soobshcheniya o nastroeniyakh naseleniya $\mathrm{v}$ TsK VKP(b) [Information and Reports on the Moods of the Population in the Central Committee of the All-Union Communist Party (Bolsheviks)]. Rossiyskiy gosudarstvennyy arkhiv sotsialno-politicheskoy istorii [Russian State Archive of Socio-Political History], F.17, Op. 121, D. 212.

13. Kabirova A.Sh. Massovoe soznanie naseleniya Tatarstana $\mathrm{v}$ gody Velikoy Otechestvennoy voyny (1941-1945) [Mass Consciousness of the Population of Tatarstan during the Great Patriotic War (1941-1945)]. Vtoraya mirovaya voyna kak problemy natsionalnoy pamyati: materialy mezhdunar. nauch. konf. (24-26 sent. 2009 g., g. Sankt-Peterburg) [World War II as a Problem of National Memory: Materials of International Academic Conference (September 24-26, 2009, Saint Petersburg)]. Saint Petersburg, Izd-vo RGPU im. A.I. Gertsena, 2010, pp. 111-124.

14. Kozlov N.D., Dovzhinets M.M. Ofitsialnoe $i$ obydennoe soznanie $v$ gody Velikoy Otechestvennoy voyny [Official and Everyday Consciousness During the Great Patriotic War]. Saint Petersburg, Alter Ego Publ., 2008. 336 p.

15. Kommunist (Organ Saratovskogo obkoma $i$ gorkoma VKP (b), Oblispolkoma i Gorsoveta) [Communist (The Body of the Saratov Regional Committee and City Committee of the All-Union Communist Party (Bolsheviks), Regional Executive Committee and City Council], 1945, January 7. (Leading article).

16. Kondakova N.I. Voyna, gosudarstvo, obshchestvo. 1941-1945 [War, State, Society. 19411945]. Moscow MGF "Veteran Moskvy” Publ., 2002. $480 \mathrm{p}$.

17. Krinko E.F. Istoriya Vtoroy mirovoy voyny v slukhakh [History of World War II in Rumours]. Vestnik Sochinskogo gosudarstvennogo universiteta turizma i kurortnogo dela. Nauchnyy zhurnal, 2008, iss. 12 (34), pp. 194-203.

18. Makarenko Ya. Rabovladeltsy-istyazateli [Slave Owners-Torturers]. Kirzhachskiy udarnik (Organ Kirzhachskogo gorkoma i raykoma VKP (b) [Kirzhach Shock Worker (The Body of the Kirzhach City Committee and District Committee of the All-Union Communist Party (Bolsheviks)], 1942, September 25.

19. Pismo-obrashchenie rabotnikov $\mathrm{z}$-da im. Maslennikova. Spravki i otkliki [Letter of Address on 


\section{СТРАЛИНГРАДСКИЙ ТЫЛ}

Behalf of Workers of the Plant Named After Maslennikov. References and Responses]. Samarskiy oblastnoy gosudarstvennyy arkhiv sotsialnopoliticheskoy istorii [The Samara Regional State Archive of Socio-Political History], F. 656, Op. 33, D.74.

20. Potemkina M.N. Evakuatsiya v gody Velikoy Otechestvennoy voyny na Urale: lyudi i sudby [Evacuation During the Great Patriotic War in the Urals: People and Fates]. Magnitogorsk, MaGU Publ., 2002. $265 \mathrm{p}$.

21. Put Lenina (Organ Ulyanovskogo raykoma $V K P(b) \quad i$ rayonnogo Soveta deputatov trudyashchikhsya) [The Way of Lenin (The Body of the Ulyanovsk District Committee of the All-Union Communist Party (Bolsheviks) and the District Council ofWorking People's Deputies)], 1943, January 1 (no. 1), p. 1. (Leading article).

22. Savushkin L.M. Ideologiya sovetskogo tyla: problemy i protivorechiya, 1941-1945 gg.: (Opyt deyatelnosti part. org. tylovykh r-nov RSFSR) [The Ideology of the Soviet Rear: Problems and Contradictions, 1941-1945: (Experience of the Activities of the Party Organizing Rear Regions of the RSFSR)]. Voronezh, Izd-vo Voronezh. un-ta, 1990. 191 p.

23. Senyavskaya E.S. Geroicheskie simvoly: realnost i mifologiya voyny [Heroic Symbols: Reality and Mythology of War]. Otechestvennaya istoriya, 1995 , no. 5 , pp. $30-44$.

24. Simonov K. Ubey ego [Kill Him]. Krasnaya zvezda, 1942, July 18.

25. Livshin A.Ya., Orlov I.B. Sovetskaya povsednevnost i massovoe soznanie 1939-1945 [Soviet Everyday Life and Mass Consciousness in 1939-1945]. Moscow, ROSSPEN Publ., 2003. 472 p.

26. Livshin A.Ya., Orlov I.B. Sovetskaya propaganda $v$ gody Velikoy otechestvennoy voyny: «kommunikatsiya ubezhdeniya» $i$ mobilizatsionnye mekhanizmy [Soviet Propaganda During the Great Patriotic War: "Communication of Persuasion" and Mobilization Mechanisms]. Moscow, ROSSPEN Publ., 2007. 806 p.

27. Somov V.A. Pervoe sovetskoe pokolenie: ispytanie voynoy [The First Soviet Generation: The Test of War]. Moscow, AIRO-XXI Publ., 2015. 176 p.

28. Somov V.A. Potomu chto byla voyna... Vneekonomicheskie faktory trudovoy motivatsii $v$ gody Velikoy Otechestvennoy voyny (1941-1945) [Because There Was a War ... Non-Economic Factors of Labor Motivation During the Great Patriotic War (1941-1945)]. Nizhny Novgorod, Izd-vo VolgoVyatskoy akademii gosudarstvennoy sluzhby, 2008. $234 \mathrm{p}$.

29. Somov V.A. Slukhi kak faktor trudovogo povedeniya $\mathrm{V}$ nachalnyy period velikoy otechestvennoy voyny [Rumors as the Factor of Labour Behaviour at the Beginning of the Great
Patriotic War]. Istoricheskaya psikhologiya $i$ sotsiologiya istorii [Historical Psychology and Sociology of History], 2011, no. 1, pp. 19-32.

30. Soobshchenie Sverdlovskogo UNKVD v TsK VKP(b) ob otklikakh uchenykh na deystviya soyuznikov v Afrike [Report of the Sverdlovsk UNKVD to the Central Committee of the All-Union Communist Party (Bolsheviks) on the Responses of Scientists to the Actions of the Allies in Africa]. Rossiyskiy gosudarstvennyy arkhiv sotsialno-politicheskoy istorii [Russian State Archive of Socio-Political History], F. 17, Op. 125, D. 84.

31. Soobshcheniya UNKVD v Kuybyshevskiy obkom VKP(b) [Communications of the NKVD to the Kuibyshev Regional Committee of the All-Union Communist Party (Bolsheviks)]. Samarskiy oblastnoy gosudarstvennyy arkhiv sotsialno-politicheskoy istorii [The Samara Regional State Archive of SocioPolitical History], F. 656, Op. 22, D. 20.

32. Soobshcheniya UNKVD v Kuybyshevskiy obkom VKP(b) [Communications of the NKVD to Kuybyshevsky Regional Committee of the All-Union Communist Party (Bolsheviks)]. Samarskiy oblastnoy gosudarstvennyy arkhiv sotsialno-politicheskoy istorii [The Samara Regional State Archive of SocioPolitical History], F. 656, Op. 33, D. 25.

33. Soobshcheniya UNKVD v Kuybyshevskiy obkom VKP(b) [Communications of the NKVD to the Kuibyshev Regional Committee of the All-Union Communist Party (Bolsheviks)]. Samarskiy oblastnoy gosudarstvennyy arkhiv sotsialno-politicheskoy istorii [The Samara Regional State Archive of SocioPolitical History], F. 656, Op. 33, D. 38.

34. Soobshcheniya UNKVD v Kuybyshevskiy obkom VKP(b) [Communications of the NKVD to the Kuibyshev Regional Committee of the All-Union Communist Party (Bolsheviks)]. Samarskiy oblastnoy gosudarstvennyy arkhiv sotsialno-politicheskoy istorii [The Samara Regional State Archive of SocioPolitical History], F. 656, Op. 34, D. 62.

35. Spravki i dokladnye zapiski Kuybyshevskogo obkoma VKP(b) [References and Memoranda of the Kuibyshev Regional Committee of the All-Union Communist Party (Bolsheviks)]. Samarskiy oblastnoy gosudarstvennyy arkhiv sotsialno-politicheskoy istorii [The Samara Regional State Archive of SocioPolitical History], F. 656, Op. 33, D. 72.

36. Spravki i dokladnye zapiski TsK VKP(b) [References and Memoranda of the Central Committee of the All-Union Communist Party (Bolsheviks)]. Rossiyskiy gosudarstvennyy arkhiv sotsialnopoliticheskoy istorii [Russian State Archive of SocioPolitical History], F. 17, Op. 125, D. 203.

37. Spravki i dokladnye UNKVD v Kuybyshevskiy obkom VKP(b) o nastroeniyakh naseleniya [References and Reports to the NKVDD in 
the Kuibyshev Regional Committee of the All-Union Communist Party (Bolsheviks) on the Population Moods]. Samarskiy oblastnoy gosudarstvennyy arkhiv sotsialno-politicheskoy istorii [The Samara Regional State Archive of Socio-Political History], F. 656, Op. 20, D. 33 .

38. Spravki i dokladnye TsK VKP(b) [References and Reports to the Central Committee of the All-Union Communist Party (Bolsheviks)]. Rossiyskiy gosudarstvennyy arkhiv sotsialno-politicheskoy istorii [Russian State Archive of Socio-Political History], F. 17, Op. 43, D. 1474.

39. Spravki i perepiska Kuybyshevskogo obkoma VKP(b) [References and Correspondence of the Kuibyshev Regional Committee of the All-Union Communist Party (Bolsheviks)]. Samarskiy oblastnoy gosudarstvennyy arkhiv sotsialno-politicheskoy istorii [The Samara Regional State Archive of SocioPolitical History], F. 656, Op. 33, D. 35.

40. Spravki o nastroeniyakh naseleniya [References on Population Moods]. Samarskiy oblastnoy gosudarstvennyy arkhiv sotsialnopoliticheskoy istorii [The Samara Regional State Archive of Socio-Political History], F. 656, Op. 20, D. 32.

41. Spravki, pisma, otchety Kuybyshevskogo obkoma VLKSM [References, Letters, Reports of the Kuibyshev Regional Committee of the Komsomol]. Samarskiy oblastnoy gosudarstvennyy arkhiv sotsialno-politicheskoy istorii [The Samara Regional State Archive of Socio-Political History], F. 1683, Op. 1, D. 204.

42. Spravki statisticheskogo upravleniya Kuybyshevskoy oblasti [References of the Statistical
Office of the Kuibyshev Region]. Tsentralnyy gosudarstvennyy arkhiv Samarskoy oblasti [Central State Archive of the Samara Region], F. P-2521, Op. 10, D. 73.

43. Spravki TsK VKP(b) [References of the Central Committee of the All-Union Communist Party (Bolsheviks)]. Rossiyskiy gosudarstvennyy arkhiv sotsialno-politicheskoy istorii [Russian State Archive of Socio-Political History], F. 17, Op. 43, D. 1053.

44. Spravki TsK VKP(b) po zavodu im. Dzerzhinskogo [Information from the Central Committee of the All-Union Communist Party (Bolsheviks) on the Dzerzhinsky Plant]. Rossiyskiy gosudarstvennyy arkhiv sotsialno-politicheskoy istorii [Russian State Archive of Socio-Political History], F. 17, Op. 125, D. 108.

45. Tkacheva G.A. Dalnevostochnoe obshchestvo $v$ gody Velikoy Otechestvennoy voyny (1941-1945 gg.) [Far Eastern Society in the Years of the Great Patriotic War (1941-1945)]. Vladivostok, Dalnauka Publ., 2010.376 p.

46. Tochenov S.V. Nastroeniya naseleniya Ivanovskoy oblasti na nachalnom etape Velikoy Otechestvennoy voyny (iyun-avgust 1941 goda) [Moods of Population in the Ivanovo Region at the Beginning of the Great Patriotic War (June-August 1941)]. Vestnik IvGU. Seriya Gumanitarnye nauki. Nauchnye statyi [Bulletin of the Ivanovo State University. Humanities. Academic Papers], 2008, iss. 4, pp. 43-52.

47. Sholokhov M.A. Nauka nenavisti [Science of Hatred]. Pravda, 1942, June 22.

48. Erenburg I. Ubey [Kill]. Krasnaya zvezda, 1942 , July 24.

\section{Information about the Author}

Vyacheslav N. Paramonov, Doctor of Sciences (History), Professor, Department of National History and Historiography, Samara National Research University named after S.P. Korolev, Moskovskoe Shosse St., 34, 443086 Samara, Russian Federation, parvja@mail.ru. https://orcid.org/0000-0002-9573-5469

\section{Информация об авторе}

Вячеслав Николаевич Парамонов, доктор исторических наук, профессор кафедры отечественной истории и историографии, Самарский национальный исследовательский университет им. С.П. Королева, ул. Московскоешоссе, 34, 443086 г. Самара, Российская Федерация, parvja@mail.ru, https://orcid.org/0000-0002-9573-5469 